\title{
КАРГАЛИНСКАЯ ДИАДЕМА ПОД ФЛЕРОМ ЮРИЯ ДОМБРОВСКОГО
}

\section{(C) 2021 г. Сараев Владимир Васильевич ${ }^{1}$}

${ }^{1}$ специалист естественных наук, Институт археологии им. А.Х. Маргулана, г. Алматы, Казахстан. E-mail: saraev.53@mail.ru

\begin{abstract}
Аннотация. В статье представлены результаты проведенных исследований, раскрывающих историю обнаружения погребения, известного в литературе как «Шаманское погребение на реке Каргалинке». На основе архивных данных, опроса местных жителей-старожилов автору удалось воссоздать историю обнаружения памятника и его дальнейшую судьбу. Раскрыта роль участников события и дальнейшая судьба как людей, так и предметов погребения. Особое значение имеет обнаружение точного места захоронения, сопровождаемого комплексом золотых предметов. Этот факт имеет большое значение для истории науки, а также для культурно-исторической атрибуции памятника, с учетом памятников археологии, выявленных в районе места Каргалинского захоронения. Представленная статья отличается легкостью изложения, обилием интересных фактов, представляет собой пример настойчивости и системности в изложении вопроса истории науки (данное издание является своеобразным Предисловием к материалам, публикуемых в этом номере, подготовленных под руководством А.А. Горячева об итогах изучения археологического комплекса Каргалинского историкогеографического микрорайона в полевом сезоне 2020 г. - прим. ред.).
\end{abstract}

Ключевые слова: археология, Каргалы, усуни, погребение, клад, история науки

\section{ЮРИЙ ДОМБРОВСКИЙДІН ФЛЕР АСТЫНДАҒЫ ҚАРҒАЛЫ ДИАДЕМАСЫ}

\section{Сараев Владимир Васильевич ${ }^{1}$}

\author{
${ }^{1}$ жаратылыстану ғылымдарының маманы, Ә.Х. Марғұлан атындағы \\ Археология институты, Алматы қ., Қазақстан. E-mail: saraev.53@mail.ru
}

Аннотация. Мақалада әдебиетте «Қарғалы өзеніндегі бақсылық жерлеу» деген атпен танымал жерлеуді анықтау тарихын ашуға жүргізілген зерттеулердің нәтижелері келтірілген. Архив деректері, жергілікті байырғы тұрғындар арасындағы жүргізілген сауалнамалар негізінде автор ескерткіштің табылу тарихын және оның болашақ тағдырын қалпына келтіре алды. Оқиғаға қатысушылардың рөлі және адамдардың да, жерлеу заттарының да тағдыры ашылды. Алтын заттар кешенімен бірге нақты жерлеу орнын табу ерекше маңызды. Бұл факт ғылым тарихы үшін, сондай-ақ Қарғалы жерлеу орны ауданында анықталған археология ескерткіштерін ескере отырып, ескерткіштің мәдени-тарихи атрибуциясы үшін де үлкен маңызға ие. Ұсынылған мақала жеңіл баяндалуымен, қызықты фактілердің көптігімен ерекшеленеді, ғылым тарихы мәселесін ұсынуда табандылық пен жүйеліліктің мысалы болып табылады (Бұл басылым А.А. Горячевтің жетекшілігімен 2020 ж. далалық маусымда Қарғалы тарихи-

Работа выполнена при финансовой поддержке Комитета науки МОН РК, программно-целевое финансирование на 2021-2022 гг. 
географиялық шағын ауданының археологиялық кешенін зерделеу қорытындысы туралы дайындалған осы нөмірде жарияланған материалдарға өзіндік алғы сөз болып табылады - ред.).

Түйін сөздер: археология, Қарғалы, үйсін, жерлеу, көмбе, ғылым тарихы

\title{
KARGALY DIADEMA ON A NOTE OF YURI DOMBROVSKIY
}

\author{
Saraev Vladimir ${ }^{1}$ \\ ${ }^{1}$ Specialist in Natural Sciences, A.Kh. Margulan Archeology Institute, \\ Almaty, Kazakhstan. E-mail: saraev.53@mail.ru
}

\begin{abstract}
The article presents the results of studies that reveal the history of the discovery of the burial, known in the literature as "Shaman burial on the Kargalinka River". Based on archival data, a survey of local long-term residents, the author managed to recreate the history of the discovery of the monument and its future fate. The role of the participants in the event and the further fate of both people and objects of burial was revealed. Of particular importance is the discovery of the exact place of burial, accompanied by a complex of gold objects. This fact is of great importance for the history of science, as well as for the cultural and historical attribution of the monument, taking into account the archaeological monuments identified in the area of the place of the Kargaly burial. The presented article is distinguished by its simplicity of presentation, an abundance of interesting facts, and is an example of perseverance and consistency in the presentation of the question of the history of science (This publication is a kind of preface to the materials published in this issue, prepared under the guidance of A.A. Goryachev on the results of studying the archaeological complex of the Kargaly historical and geographical microdistrict in the 2020 field season - eds.).
\end{abstract}

Keywords: archaeology, Kargaly, Wusun, burial, treasure, history of science

\section{Вступительное слово}

Сегодня, 23 августа 2020 г., я могу взять в руки и внимательно рассмотреть круглые выпуклые золотые бляшки различного диаметра с маленькими отверстиями у края. Это вещи, которые еще не попали в музей, но они - составная часть известного «Каргалинского клада». Они появились в результате работы небольшого археологического отряда под руководством А.А. Горячева (см.: [Горячев и др., 2021] - прим. ред.).

Предваряя рассказ об изысканиях на тему Каргалинской находки, приведших к успешному финалу, хочется высказать благодарность всем людям, причастным к сбору сведений для явления события сегодняшнего дня. Любопытно, но, рассматривая вещи, найденные археологами, появилась мысль о том, что если бы мне довелось какую-то из этих бляшек увидеть брошенной на дороге, то я не дал бы себе труда нагнуться за ней. Но на то чтобы сегодня подержать в руках эти круглые бляшки у меня ушло 42 года жизни! Это не просто мятые золотые кругляшки. Это составная часть известного «Каргалинского клада». И, вероятно, оно стоило того.

Обращаясь в памяти к прошедшим годам розыска и людям, причастным к поиску места находки клада, понимаю, что ни один человек, так или иначе причастный к сбору фактов и разведке места находки этого клада, не смог бы, каждый в отдельности, найти это место. Парадоксально, но 
Cараев В.B. Каргалинская диадема под флером Юрия Домбровского

все решил «Господин Случай». Однако, как много сведений необходимо было собрать в единый эмоциональный клубок, чтобы сработала случайность. Объективно, сегодня никто из людей, причастных к этим поискам, не может сказать, что это место нашел именно он. У меня есть чувство гордости за мой вклад в поиск места уникальной Каргалинской находки.

\section{Зерна от плевел}

Недавно, в частной переписке, один из археологов, работающих в настоящее время, сказал, что, по его мнению, никому не нужна никакая статья про Каргалинскую диадему, поскольку под флером Юрия Домбровского «Факультета ненужных вещей» и так все ясно, и не писал на эту тему только ленивый (см. о Ю. Домбровском: [Бейсенов и др., 2017, с. 15-16]). Действительно, на тему Каргалинского клада или Каргалинской диадемы написано много. Даже фильмы есть. Однако многое из написанного на эту тему изобилует домыслами и фантазиями «на тему о..». И чаще всего эти повествования больше напоминают лоскутное одеяло, чем источник достоверной информации. Понятно, что авторы различных произведений имеют право на «авторское видение» и «литературные приемы», но каждое последующее произведение множит несуразицу сведений о Каргалинской находке. Достаточно часто эти догадки, порой довольно нелепые, касаются обстоятельств, о которых известны факты. Также обыгрываются ситуации и в фильмах о Каргалинской диадеме. Авторы, стараясь быть максимально близко к источнику наиболее достоверной информации, исключая посредников, обращаются к произведениям Юрия Домбровского как к первоисточнику. При этом они не берут во внимание то, что Домбровский в своих работах, возможно зная истинное положение вещей, искажал известные ему достоверные факты находки предметов Каргалинского клада. На то у него были свои причины. Ю.О. Домбровский, прежде всего, был литератором. Поэтому в его произведениях, таких как «Факультет ненужных вещей», либо в фильме «Шествие золотых зверей» (1978), основой конструкции является творческая фантазия автора.

Порой обстоятельства, связанные с этой находкой, доводятся до абсурда. Однажды в Центральном музее РК экскурсовод, показывая на Каргалинскую диадему, несколько раз назвала ее Карагандинской диадемой. Улучив момент, пришлось сказать женщине, что диадему нашли в Каргалинском ущелье, а не в Караганде. На что она ответила, что Караганду знают все, а кто знает ваши Каргалы? Перебор, конечно, налицо, но существующие официальные источники не дают неоспоримой однозначной информации, связанной с находкой этого исторического материала. Каргалинский комплекс называют то захоронением, то кладом. Тогда как смысл, заложенный в понятиях «клад» и «захоронение», либо «погребение», существенно отличается. Одно дело, когда в земле для сохранения укромно зарыто ранее собранное богатство и иное, когда речь идет о могиле человека в богато украшенной одежде.

В известной работе А.Н. Бернштама, изданной в 1940 г., уже в самом названии статьи «Золотая диадема из шаманского погребения на р. Карагалинке» сказано, что речь идет о захоронении [Бернштам, 1940, с. 23]. На сайте Центрального государственного 
музея Республики Казахстан (ЦГМК) сообщается, что обнаруженное погребение жрицы получило название «Каргалинский клад».

В различных источниках поразному сообщается и об обстоятельствах нахождения этих вещей. Чехарда сведений варьируется от случайных обстоятельств нахождения вещей охотниками до их обнаружения в результате проведения земляных работ либо археологических раскопок. В настоящее время в СМИ встречаются авторы, которые называют людей, нашедших Каргалинский клад, «дружной командой охотников-грабителей». Рассуждая в таком ключе, легко дойти до вывода, что государство поощряло грабителей, поскольку достоверно известно, что люди, нашедшие золото и сдавшие его государству, получили денежное вознаграждение.

Любопытно было бы знать, а как поступил бы автор этого заявления на месте охотников? Как на их месте поступил бы любой человек, много времени походивший по горам и за десяток километров от ближайшего жилья нашедший брошенные кем-то изделия, возможно, из золота? Находки надо было оставить на месте?

Задача историков и археологов сделать возможным необходимое донести факты. Правда одна. Она не имеет вариантов. Убеждение в том, что тот, кто занимается вопросами истории и археологии, обязан интерпретировать и комментировать сугубо объективный фактический материал и побудили написать все, что известно мне об этой непростой истории находки Каргалинского клада.

\section{Свидетели и документьл}

Увидеть некоторые моменты под флером (легкая вуалевая накид- ка), в смысле, познакомиться с фактами событий, связанными с находкой Каргалинского клада, довелось в силу ряда сложившихся обстоятельств. Главным из которых было то, что большую часть своей жизни я прожил в поселке Фабричный (Жамбылский район Алматинской обл.), в котором и происходили события, связанные с этой находкой, и мне довелось жить среди людей, причастных к этим делам.

Впервые сознательно соприкоснуться с вопросом Каргалинской находки случилось в 1978 г. Ко мне, учителю физики Каргалинской СШ № 1, обратилась учитель русского языка и литературы Полина Андреевна Яковенко (рис. 1) и спросила - нет ли у меня каких-либо фотографий пещер наших гор. Помимо работы преподавателя по физике, в этой школе я был руководителем кружка фотолюбителей, школьной киностудии и увлекался туризмом. Таких фотографий у меня не оказалось. Только позже стало понятно, зачем они были ей нужны. Во второй половине лета этого же года Полина Андреевна попросила меня посодействовать ей в записи на магнитофон рассказа одного из старых жителей нашего поселка о том, как они с друзьями на охоте нашел клад золота. Так я оказался в доме Николая Сергеевича Есипова. Запись рассказа Николая Сергеевича проводилась долго, часа 2-3. Его воспоминания событий 1939 г. часто прерывались сильнейшим надрывным кашлем, после которого он просил возможности немного отдохнуть. С Первой мировой войны он носил в легких немецкую пулю. За время его рассказа и ответов на вопросы я понял, что Полина Андреевна по всему поселку у местных охотников и туристов собирала фотографии видов 
Capaeв B.B. Каргалинская диадема под флером Юрия Домбровского

различных пещер гор у поселка. Она показывала их Николаю Сергеевичу, чтобы он смог показать в какой из них охотники нашли клад. Н.С. Есипов среди показанных ему фотографий не указал ни на одну. Стало ясно, что фотографии пещеры, в которой были найдены золотые вещи, нет. Понять из объяснений Н.С. Есипова, в каком месте находится эта пещера, было крайне трудно. Рассказ Николая Сергеевича, записанный на магнитофон, отредактированный Полиной Андреевной и переложенный на бумагу, выглядит так: «Рассказывает Есипов Николай Сергеевич. 1939 год, конец лета. Каргалинская суконная фабрика. Четверо рабочих фабрики: Есипов Николай Сергеевич - прораб, Назаренко Аркадий Васильевич - токарь, Семин - шеф-монтер из Москвы, а четвертого не помню, в субботний вечер пошли в горы на охоту. В 30 км от поселка прямо по ущелью остановились на ночлег под большим нависающим камнем. Накрапывал дождь. Развели костер, готовили походный ужин. Аркадий Назаренко от нечего делать палочкой ковырял камешки. Выскочила поясная бляха, такие носили казахи, ее кто-то выбросил к речке. Что-то сказали Аркадию, он не унимался и продолжил ковырять. Обнаружились еще предметы: колечко, браслет. Посмотрели - похоже на золото. Чуть рассвело - стали копать, нашли еще несколько пластинок и колец. Утратив интерес к охоте, пошли домой. Показали найденные вещи химику отделочного цеха товарищу Ахметову, тот проверил и оказалось, что золото. Тогда мы опять отправились к заветному камню. Накопали около 2,5 кг украшений женских: диадема с изображением мифического сюжета, пластинки с архарами, орнаментом,

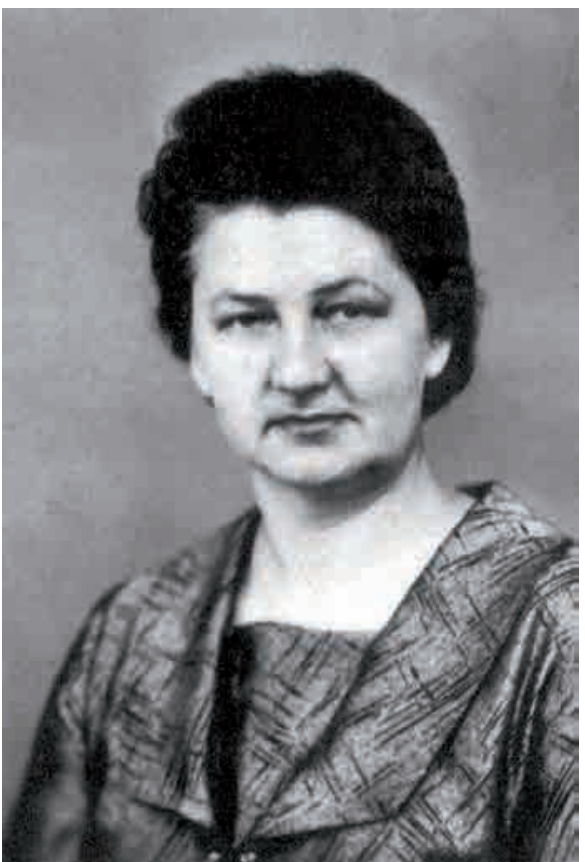

Рис. 1. Яковенко Полина Андреевна, учитель русского языка и литературы Каргалинской СШ № 1. Фото из архива Каргалинской СШ № 1

Fig. 1. Yakovenko Polina, teacher of the Russian language and literature of the Kargaly secondary school no. 1. Photo from the archive of the Kargaly School no. 1

около 300 пуговиц мелких и покрупнее, ими, вероятно, обшито платье, кое-где была видна сетка ткани. Все через Семина сдали в центральный краеведческий музей г. Алма-Ата (ныне Алматы - прим. авт.). Через некоторое время к нам приехал из Ленинграда археолог, фамилию его я не знаю, помню, что это был человек лет под 50, прихрамывал. Я сопровождал его к месту находки.

Ехать на лошади он отказался и просил не показывать места находки. Пошли пешком, во время пути он все присматривался к камням и вдруг закричал: “Нашел!". А нашел он камень с очень тусклым изображением зверя с рогами и крыльями, бегущего в 
горы. Таких камней на своем пути мы встретили несколько, а когда нашли камень с изображением какого-то зверя, бегущего с гор, археолог остановился и сказал: “Где-то здесь, теперь показывайте”. Да, захоронение было здесь. Археолог высказал предположение, что через наше ущелье проходил караванный путь из Китая. Изображение свиньи на камне тоже связано с Китаем. В Китае свинья - священное животное. На другой день я сопровождал его в поездке по окрестностям поселка. Комбинат (Каргалинский суконный комбинат - прим. авт.) выделил ему машину на два дня, двоих рабочих. С левой стороны дороги, ведущей в Узын-Агач (ныне Узынагаш - прим. авт.), где раньше была карагачевая роща, а позже рабочие комбината посадили огороды, он обратил внимание на камни, лежавшие кольцом, их было семь, с внутренней стороны закопченные, а в середине большой слой золы. Рабочие раскопали этот жертвенник. Предположение о караванном пути подтверждается этой находкой. После перехода через горы, здесь, на равнине, близко от воды располагался караван на отдых, приносили жертвы, стекались местные кочевники, устраивали большой той.

Рассказал Есипов, записала Яковенко Полина Андреевна. 18.08 .78 года».

В данном изложении рассказа Н.С. Есипова говорится, что на охоту они пошли вчетвером. Однако, как я помню и по различным сведениям, собранным за много лет, получается, что на охоту они ходили втроем. Когда вели запись рассказа Есипова на магнитофон, то произошел спор Николая Сергеевича с супругой по вопросу, сколько человек их было на охоте. Сошлись на том, что их было трое. Во всяком случае, перечислить по фамилиям получалось только так. Невозможность однозначно назвать количество охотников, бывших на охоте, произошла потому, что не все те, кто собирался на охоту, пошли в тот день.

После записи рассказа Н.С. Есипова Полина Андреевна поделилась своими планами на будущее. Как оказалось, она готовилась к уходу из школы на пенсию и собирала материалы для создания музея Каргалинского суконного комбината. Попросила помощи в сборе фактического материала (рис. 2, 3)* Ее усилиями был создан замечательный музей комбината, который в настоящее время не существует.

В последующее время работы по сбору фактов находки Каргалинского клада выяснилось, что Н.С. Есипов в своем рассказе, в силу преклонного возраста и плохого физического самочувствия, некоторые моменты путал, забывал, а местами в чем-то и искренне заблуждался. Например, он сказал, что жертвенник из камней, уложенных кругом, расположен на берегу реки Узун Каргалы в 250 м от русла. На самом деле его удалось найти в указанном направлении на расстоянии более 2 км. В своем рассказе Николай Сергеевич говорит, что в месте, найденном ими, собрали около 2,5 кг

*Небольшое пояснение к рис. 2 и 3 о личности К.П. Бирюкова: Бирюков Кузьма Павлович, в военные годы, рискуя жизнью, сумел подать воду на Комбинат. На суконном комбинате остановилась гидроэлектростанция и все производство, поскольку вся вода на комбинат, идущая по трубам перемерзла. Бирюков К.П. залез внутрь трубы и более 500 метров от выхода нашел ледяную пробку и ломом, прорубил ее. Производство было запущено. (Прим. авт.). 
Сараев В.B. Каргалинская диадема под флером Юрия Домбровского

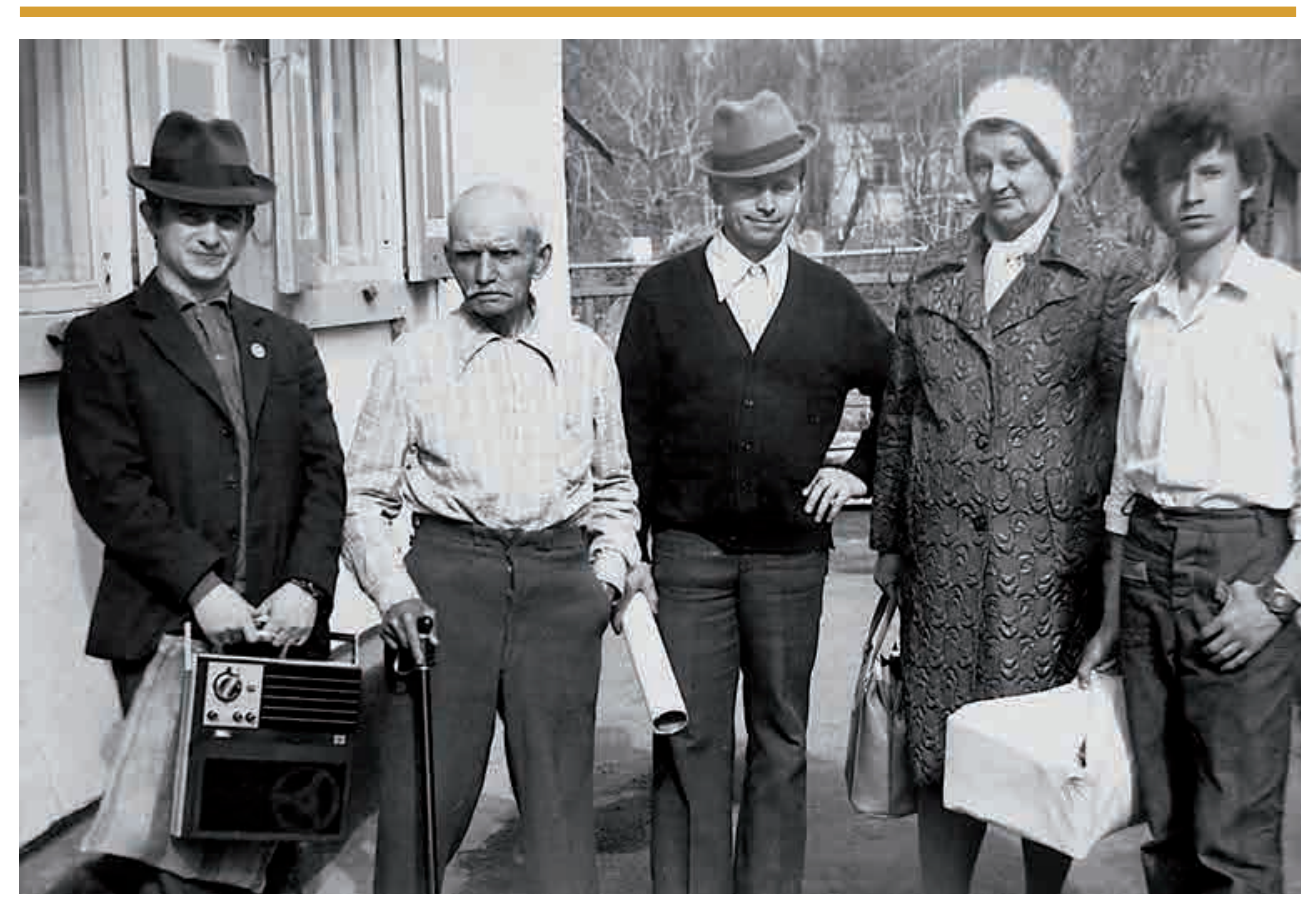

Рис. 2. Полина Андреевна с рабочей группой во дворе старожила Бирюкова Кузьмы Павловича. Фото из архива Каргалинской СШ № 2

Fig. 2. Yakovenko Polina with a working group in the courtyard of the long-term resident Biryukov Kuzma. Photo from the archive of the Kargaly School no. 2

золотых изделий. В настоящее время такая же информация встречается в некоторых печатных изданиях и Интернете со ссылкой на Н.С. Есипова.

Вместе с тем существует официальный документ, дающий описание вещей Каргалинской находки: «В Центральный государственный музей Казахской ССР за последние годы поступил целый ряд интересных археологических находок. В 1939 г. в правом ответвлении Каргалинского ущелья Алма-Атинской области близ урочища Мынг-Ошакты на высоте 2300 м над уровнем моря случайно были найдены кости человека с набором золотых предметов в количестве около 300 штук. Скелет был найден в расщелине скалы. По определению доктора исторических наук А.Н. Бернштама, вещи принадлежат захоронению шамана и датируются I в. до н.э. - II в. н.э.
Ниже дается общее количественное описание всех предметов коллекции:

1. Два фрагмента золотой диадемы, общим весом 89,59 г;

2. 53 круглые выпуклые золотые пластинки, диаметром 1,5 см, (средний вес одной пластинки - 0,462 г);

3. 85 круглых выпуклых золотых пластинок, полых внутри, из них - 67 диаметром 0,7 см, 16 пластинок, орнаментированных семью выпуклыми точками, диаметром 0,9 см и две неполные пластинки (средний вес одной пластинки 0,131 г);

4. 63 круглых пластинки полых внутри, диаметром 11 см (средний вес отдельной пластинки 0,25 г);

5. Пять листовидных пластинок больших размеров, длиной 2,5 см, шириной 1,8 см (вес отдельной пластинки 1,091 г); 


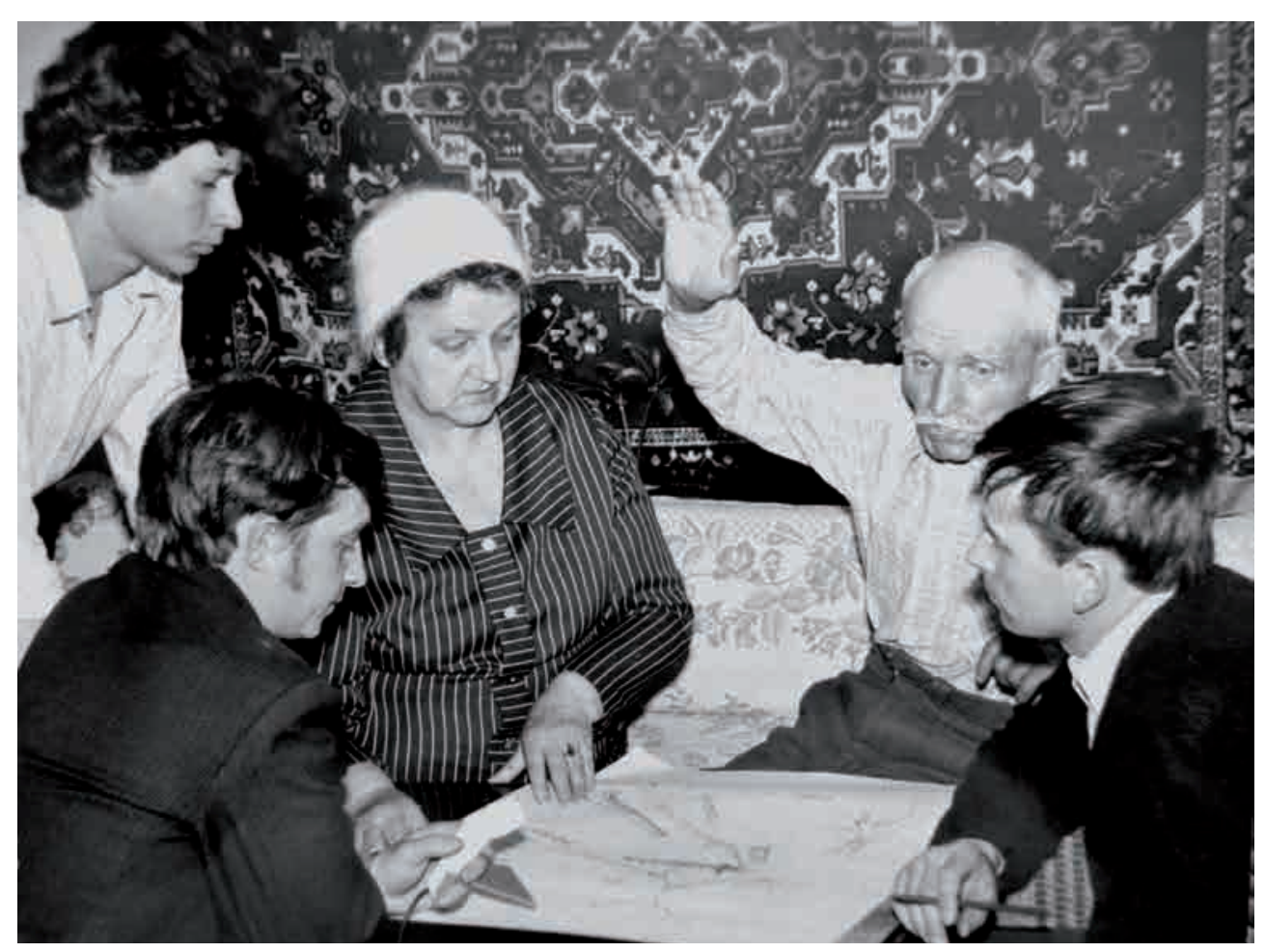

Рис. 3. Запись рассказа К.П. Бирюкова о прошлом пос. Фабричный. Фото из архива Каргалинской СШ № 2

Fig. 3. Record of the story of K. Biryukov about the village Fabrichny past. Photo from the archive of the Kargaly School no. 2

6. 28 листовых пластинок меньших размеров, длиной $2 \mathrm{~cm}$, шириной 1,3 см (средний вес отдельной пластинки 0,458 г);

7. 10 рельефных золотых украшений, изображающих тау-теке, шириной 2 см, длиной 2,4 см (вес отдельного украшения от 1,07 до 1,45 г);

8. Два золотых украшения сердцевидной формы, орнаментированных рельефно, одно с поломанным концом. Длина 4 см, ширина 2,8 cм (вес отдельного украшения 2,175 г);

9. Пластинка золотая, рельефная, выпуклая, украшенная бирюзой. Длина 2,8 см, ширина 2,8 см (вес 5,35 г);

10. Две золотых выпуклых крестообразных пластинки с пятью би- рюзовыми камнями каждая, в одной пластинке нет двух камней. Ширина 0,5 см, длина 1,8 см, общий вес 2,65 ;

11. Две плоские и лентообразные золотые пластинки, длиной 7 и 5,8 см, шириной 1 и 1,4 см, общий вес 7,79 г;

12. Два золотых перстня с изображением двугорбых верблюдов, украшенных бирюзой, диаметром 1,5-2,3 см вес 12 г. Высота верблюда 1,4-1,5 см, длина 2-2,5 см;

13. Серьга в виде мыши, поедающей человека (вес 7,25 г), украшенная бирюзовыми камнями в гнездовой конструкции;

14. Четырех- и треугольные золотые рельефные пластинки (средний вес одной пластинки 0,105 г); 
Cараев B.B. Каргалинская диадема под флером Юрия Домбровского

15. 11 сердцевидных рельефных золотых пластинок, длина - 1,5 см, ширина - 0,9 см. Одна круглая с крестообразным рельефным украшением, средний ее вес 0,277 г;

16. 23 кусочка тонких золотых пластинок разных видов (общий вес 2,53 г)» [цит. по: Нифонтова, 1948, c. 116-117].

Соответственно этому списку предметов - 292, общим весом 217,417 г. Даже если принять во внимание путаницу, которую вносят пункты 7 и 14 (согласно манере описания), то 2,5 кг совершенно преувеличенное более чем в 10 раз значение веса найденных предметов. Общее количество предметов 292 действительно приближается к 300, а их общий вес - к 250 г, что, вероятно, и послужило ошибкой в воспоминаниях Н.С. Есипова, когда цифра 250 была озвучена как 2,5. А реально большое количество предметов не соответствовало представлению о граммах. В процессе беседы Николай Сергеевич посетовал, что в телевизионной передаче, которую он смотрел год или два назад (1978) сказали, что за сданные вещи охотники получили денежное вознаграждение. Но на самом деле никаких денег он не получал. Действительно, в 1975-1977 гг. по каналу Алма-Атинского телевидения была передача по теме Каргалинского клада. Помню, в студии за столом сидело 4-6 человек, обсуждали какие-то вопросы, связанные с Каргалинским ущельем. У меня интереса эта телепередача не вызвала (о чем сожалею в настоящее время), запомнил только, что кто-то из участников беседы говорил, что людям, сдавшим вещи клада, была выплачена денежная премия. Эту же телепередачу смотрел и Есипов. Он был обижен и возмущен тем, что на самом деле никакой премии охотникам не выплачивали. Обсуждая с Николаем Сергеевичем вопрос о выплате вознаграждения, пришлось ему напомнить, что он ведь сам сказал, что «все через Семина сдали в центральный краеведческий музей города Алматы», так, возможно, Семин и получил вознаграждение? Есипов согласился с таким предположением и добавил, что Семин буквально через день-два уехал домой в Москву.

Семин (его имя и отчество выяснить не удалось) был прикомандирован на комбинат как специалист по монтажу и наладке оборудования гидроэлектростанции, которая сооружалась в то время на территории комбината. Ко времени похода на охоту он окончил свою работу. Ему (со слов Н.С. Есипова) как москвичу и человеку, не занятому на производстве, и поручили отвезти найденное золото в Алма-Ату. Любопытно, что клад нашел Назаренко, в существующих официальных документах фигурирует фамилия Назаренко как находчика и сдатчика вещей в музей. Однако Николай Сергеевич сказал, что золото сдавать поехал Семин. Более того Николай Сергеевич говорил, что спрашивал Семина, вернувшегося из АлмаАты, что сказали в музее? Семин ответил, что поблагодарили - сказали «спасибо».

Через 40 лет вдруг обнаружилось несоответствие сведений официальных документов и человека, причастного к этому вопросу. Семин явно солгал Есипову.

Этот факт, воспринятый в 1978 г. эмоционально и Есиповым и мной, сегодня нуждается в более внимательном и детальном рассмотрении. Поскольку сведения, обретенные за прошедшее время, с позиции сегодняшнего дня уже не смотрятся как простое проявление жадности людей. 
Таким образом, комплекс золотых вещей, названный «Каргалинским кладом» был случайно найден в горах, далеко от населенных пунктов. Вещи нашли работники Каргалинского суконного комбината, которые пошли в горы на охоту. Это были: Аркадий Васильевич Назаренко - токарь Каргалинского суконного комбината, житель поселка Фабричный; Николай Сергеевич Есипов - сотрудник суконного комбината, занимавший должность прораба по строительству, житель поселка Фабричный; Семин (имя и отчество не установлено) специалист по электротехнике гидроэлектростанций. Семин на то время был прикомандированным на комбинат для установки и пуска генераторов ГЭС, строящейся на комбинате. Со слов Н.С. Есипова, Семин - житель г. Москва.

Почему в литературном переложении рассказа Н.С. Есипова для музея П.А. Яковенко написала, что их было четверо - непонятно. Во всяком случае, в памяти сестер Назаренко сохранилось, что их было трое: «Вместе с братом был еще Есипов, а другого фамилию я не помню» (из воспоминаний сестер Назаренко - прим. авт.). Сестры не могли вспомнить фамилию Семина, поскольку он не был местным жителем, и они с ним не общались.

Рабочие комбината отправились на охоту осенью 1939 г. Надо полагать, что выход на охоту был 7-8 числа октября месяца. Эти числа наиболее вероятны, поскольку рабочие производства в те годы не могли себе позволить без уважительных причин не появиться на работе. Серьезные последствия рабочих ожидали даже за опоздание на работу. В таких условиях чтобы сходить в горы поохотиться люди «подгадывали» выход в горы таким образом, чтобы иметь возможность дойти до наиболее отдаленных мест и при необходимости заночевать. В рассматриваемом случае видно, что люди позволили себе остаться ночевать. В 1939 г. 7 и 8 числа октября были субботой и воскресеньем. Возможны и другие варианты. Но в любом другом случае необходимо учитывать, что первый документ по осмотру места находки официальными лицами был подписан 16 октября 1939 г.

Николай Сергеевич Есипов о том дне охоты рассказал, что ухудшение погоды и начинающийся дождь поставили их перед необходимостью вернуться домой. Дорога была дальней, не меньше 20 км. К вечеру они были сильно уставшими и промокшими, до дома оставалось еще более 10 км, под камнем они увидели щель, в которую можно было залезть. Заглянули туда, оказалось сухо. Здесь и решили отдохнуть и переночевать.

«...Аркадий залез подальше внутрь, а мы ближе к входу. Промокли, холодно, решили развести костер. Веточки, палочки и сухую траву нашли тут же. Под камнем было сухо. Но разводить костер было неудобно. Под камнем было очень тесно, сесть невозможно - голова упирается в камень, и дым от костерка сильно щипал глаза. Дырка, через которую мы залезли, была ниже свода, вот дым и собирался над головой. Так, полулежа, стали готовить чем перекусить. Назаренко лежал ногами к нам и ковырялся палкой в земле. Через некоторое время говорит: “Смотрите, что я нашел". И показал какую-то бляху от ремня. Мы посмотрели ее и решили, что это потерял какой-то чабан. Выкинули ее к речке. Аркадию сказали, чтобы он прекратил ковыряться, а занялся приготовлением еды. Надо было открыть 
Capaeв B.B. Каргалинская диадема под флером Юрия Домбровского

консервы, у нас и бутылочка была с собой. Аркадий не унимался и продолжал ковырять. Нашел еще какието вещи. Там были истлевшие куски какой-то тряпочки, кости. Утром порылись основательно и нашли много всяких вещей. По дороге домой говорили, кто и что будет делать с этими вещами, если они вдруг окажутся золотыми. Кто-то высказал мысль, что даже если это золото, то, что от этого проку? Отдать их в церковь - пусть там украшаются...».

События этого дня в воспоминаниях сестер Аркадия Назаренко (рис. 4) рассказаны так: «...Каргалинский клад нашел наш брат Аркадий 1913 г.р. (рис. 5). Он работал на Каргалинской суконной фабрике токарем. В довоенное время помогал в установке ГЭС на р. Каргалинка. В 1939 г. он вместе со своими товарищами охотниками пошли в горы на охоту. Вместе с братом был еще Есипов, а другого фамилию я не помню. К вечеру в горах пошел сильный дождь, они стали искать укрытие и заметили небольшую расщелину, которую сверху укрывал большой камень, они спрятались здесь. Это было небольшой пещерой, где они решили отсидеться и развести костер. В пещере сделали ямку и развели огонь. Аркадий увидел - что-то блестит, он разрыл в этом месте и нашел какие-то предметы. Это были небольшие пуговки, правда, я не знаю, как их можно было пришивать, т. к. в них не было отверстия. Там они также нашли и кости...».

Дополняет и несколько уточняет ситуацию событий этого дня охоты рассказ жены Назаренко Аркадия, пересказанный ее подругой Д.М. Ананьевой. Однажды Мария (жена Аркадия) рассказала ей историю, произошедшую с ее мужем: «...Осенью

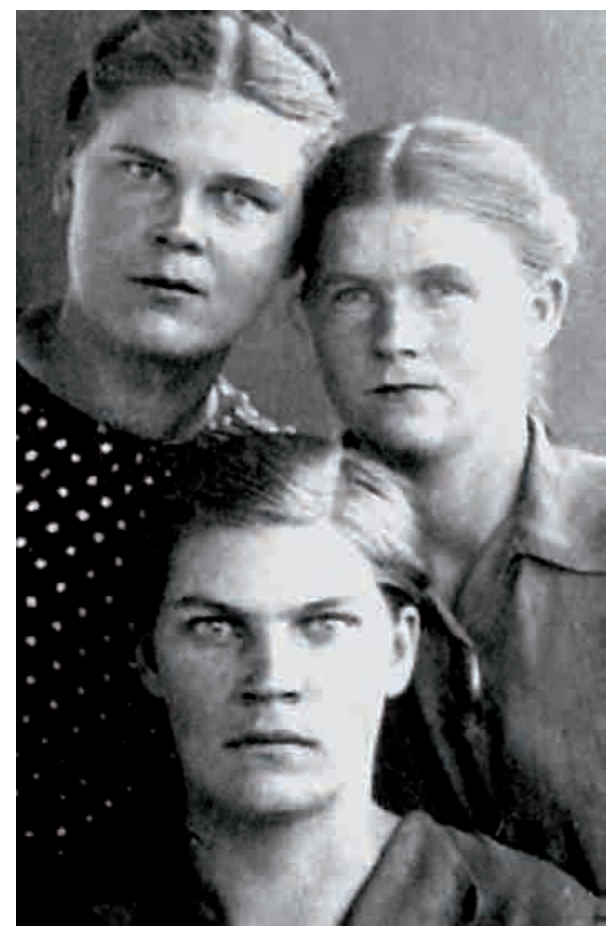

Рис. 4. Сестры А.В. Назаренко: Надя, Юля, Тамара.

Фото из архива семьи Назаренко

Fig. 4. Sisters of A. Nazarenko: Nadia, Yulia, Tamara. Photo from the archive of the Nazarenko family

1939 г. муж с друзьями-охотниками ушли в горы, очень далеко. Подстрелив большого козла, они повернули домой. По дороге домой их застал дождь и чтобы сократить дорогу, они изменили маршрут. Дождь не переставал. Они сильно промокли, как вдруг увидели отверстие в скале. Заглянув в него, решили, что в этой пещере можно отдохнуть. Разместившись в пещеpe, стали разводить костер, а Аркадий взяв палочку, стал ковырять в углу и вдруг что-то выкопал. Он решил, что это золото. Стали копать дальше и нашли много золотых вещей. Вернувшись домой, они узнали, что это, действительно, золото и сдали его государству...». 


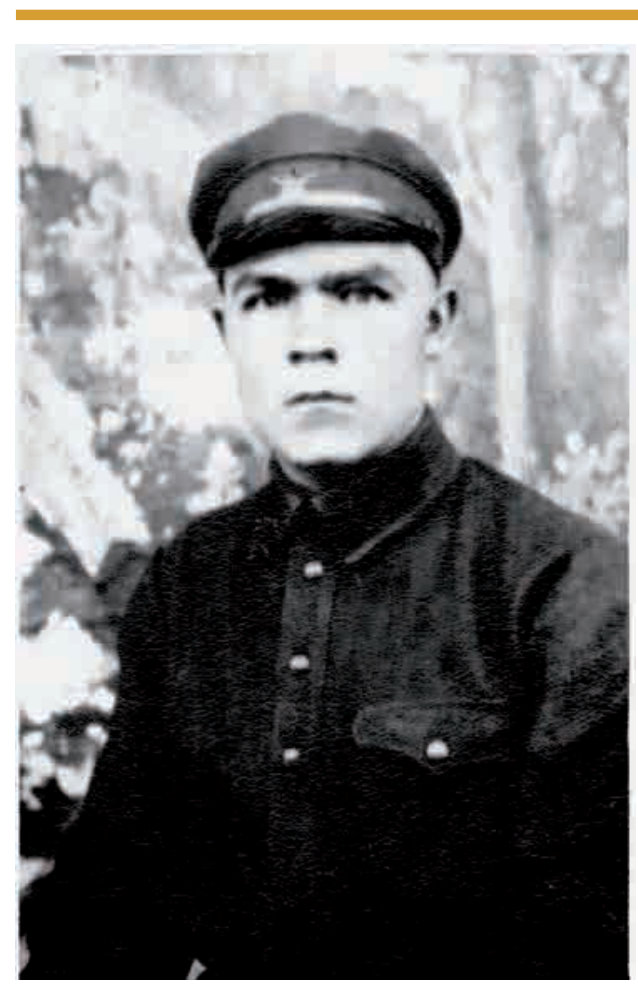

Рис. 5. Аркадий Васильевич Назаренко. Фото из архива семьи Назаренко

Fig. 5. Arkady Nazarenko. Photo from the archive of the Nazarenko family

Рассмотренные свидетельства из трех различных источников дают понимание ряда деталей. Понятно, почему охотники направились домой, имея большой запас времени на возвращение. Охота была удачной - застрелили козла. Стало понятно, почему устали, не доходя до поселка более 10 км. Несли тяжелый груз, да еще и под дождем. Большая усталость, дождь и наличие запаса времени на возвращение побудили потребность присматривать место для отдыха. Так, в силу сложившихся обстоятельств, охотники оказались в месте, где был найден клад.

Еще один момент. Н.С. Есипов упомянул, что по дороге домой обсуждали вопрос о том, что можно сделать, если находки окажутся золотыми. Это замечание Николая Сергеевича позволяет уверенно полагать, что найденные вещи поделили здесь же в горах. Как и застреленного козла. Разумеется, все делили «на глаз».

Однако ко времени записи рассказа Есипова у меня уже был какойто опыт горных походов и ночевок. Мне было непонятно, каким образом в горах, где минимум полдня шел дождь, можно было под каким-то камнем найти топливо для костра. Сухое топливо! Осенью в такой ситуации под камнем можно найти несколько пучков сухой травы, если повезет. Это сгодится для розжига. Но для костра нужны дрова. Без палок костра не получится. Под камнем, под который не попадает дождь, ничего расти не будет. Если все-таки в нише будут сухие дрова, то это значит, что их туда ктото принес. Но коль скоро их туда принесли, то почему не использовали? Я переспросил Николая Сергеевича где же они брали топливо для костра? Он ответил, что все было тут же под камнем. Для меня этот момент так и остался непонятым.

Вернувшись домой, Н.С. Есипов показал найденные вещи жене. Рассмотрели, подивились. Потом, как сказал Николай Сергеевич, он отнес находки на работу и разложил вещи на столе в кабинете. Показывал их всем интересующимся. Для определения металла, из которого были изготовлены вещи, Есипов обратился к химику отделочного цеха Ахметову. Через некоторое время Ахметов пришел и с удивлением на лице сказал, что это «настоящее червонное золото». Сдать найденные вещи государству Николаю Сергеевичу посоветовал кто-то из администрации комбината. Кто конкретно, Есипов ответить затруднился. Сказал, что уже не помнит. Среди 
Cараев B.B. Каргалинская диадема под флером Юрия Домбровского

вещей, доставшихся ему, фрагмента диадемы не было.

Ко времени похода в горы на охоту Аркадий Васильевич Назаренко, со слов старшей сестры Аркадия, 3.В. Ключниковой (1906 г.р.), жил с ней. «Аркадий первое время после свадьбы вместе с женой Марией жили у меня по улице Фабричной». Она, Зоя Васильевна, и рассказала, что один раз с охоты брат принес много золотых вещей. Она положила руки на стол и сказала, что вот этими руками она и отмывала их в чистой арычной воде. Почему-то ей особенно запомнилась какая-то квадратная бляха. Что это была за вещь, так и не удалось выяснить. Зоя Васильевна пальцами показала размер приблизительно $5 \times 5$ см. Наводящие вопросы не прояснили, о чем она говорила. Об этом предмете она эмоционально говорила как о вещи, понятной всем. Сложилось представление, что речь шла о ременной бляхе. Возможно, той, которая была первой находкой Аркадия и которую выбросили к реке. На время нашего разговора с Ключниковой, Зое Васильевне было около 100 лет, но она все хорошо помнила и вела себя очень активно.

Младшие сестры Аркадия, Юля и Надя, жили с родителями. Они рассказали, что «найденные вещи брат Аркадий решил проверить, из чего они сделаны и бросил их в кислоту. Некоторые предметы из клада мы видели. Сестра Надя мерила перстень, на котором был изображен лежащий верблюд. На его спине сидел пастух, держащий в руках палку, возле верблюда лежала собака. У верблюда глаза были голубые, так как там были вставлены голубые камни». Тогда, в 1939 г., они были подросткового возраста и достаточно эмоционально с ярким во- ображением восприняли знакомство с предметами клада. Нафантазировали пастуха с палкой и собаку у верблюда на перстне. Племянник Аркадия Назаренко - Аркадий (сын Юлии) рассказывал друзьям, что в приклад ружья дяди был врезан золотой козел. Понятно, что этот «козел» был бляшкой из Каргалинского клада.

Рассмотрение свидетельств от Есипова и родственников Назаренко дает понимание, что Аркадий Васильевич Назаренко и Николай Сергеевич Есипов, будучи жителями одного поселка и работниками одного комбината, не были в близких дружеских отношениях. Одиночный поход в горы потенциально не исключает опасности. Совместный выход в горы среди жителей поселка с детства привычная практика. Коллективный поход на охоту - обычное дело для жителей одного поселка. Это всего лишь временное объединение по интересу (к вопросу о «дружной команде охотниковграбителей»).

В то время, когда Есипов обратился к профессиональному химику для определения - из какого металла были изготовлены вещи, Назаренко бросал их в кислоту. Даже в таком простом вопросе, никого ничем не обязывающем, они не общались. Один отнес находку на работу. Рассказывал где, с кем и что нашли. Другой стал обращаться с найденными вещами как с предметами личной принадлежности. Носил некоторые вещи в кругу семьи, стал украшать приклад ружья. Складывается впечатление, что между находчиками клада не было предварительной договоренности о необходимости хранить молчание о находке и никому ничего не говорить.

К 1940 г. в поселке было около 1500 жителей, причем 1316 из них 
проживали в фабричных квартирах. Квартирами обеспечивались только работники комбината. В таких условиях, где практически все люди знали друг друга, любые новости среди населения распространялись быстро. В небольшом рабочем поселке, в котором основная часть жителей состояла из людей трудившихся на суконном комбинате, единственном производстве в селе, новость о находке распространилась быстро.

Этот момент в воспоминаниях сестер озвучен так: «А в это время кто-то из охотников сообщил о найденных вещах». Понятно, что девочки-подростки (сестрам Аркадия Назаренко в то время было 11-16 лет) не знали деталей и тонкостей отношений среди взрослых, но они передали эмоциональное отношение семьи Назаренко к этому факту. Есть основание предполагать, что между находчиками клада произошли расхождения во взглядах на использование вещей еще до момента сдачи золота государству.

При этом, разумеется, и Семин и Аркадий Назаренко знали, что инициировал ситуацию, в которой возникла необходимость сдать золото, Есипов. И оценили они это, похоже, отрицательно. Наиболее вероятно, что размолвка между Назаренко и Есиповым возникла по причине, которую спровоцировал Н.С. Есипов своим отношением к найденным вещам, он никому специально ничего не сообщал, просто он ни от кого ничего не скрывал. По существу дела сработала бытующая социальная обстановка и личное понимание права каждого находчика на обращение с найденными вещами.

Вероятно, по этой причине Назаренко не общался с Есиповым и по- средником между ними стал Семин. Семин взял у Есипова часть золота, доставшуюся Николаю Сергеевичу после дележа, и сказал, что отвезет в город сдавать. Семин солгал Есипову, сказав ему, что он, как человек окончивший работу на комбинате, отвезет вещи в музей. Семин солгал Есипову, сказав, что в музее только поблагодарили. Семин не сказал Есипову, что за сданное золото выплатили деньги. Более того, в отмщение виновнику сложившейся ситуации Семин вместе с Назаренко не дали части полученных денег, причитающуюся за ту долю золота, которую они взяли у Есипова для сдачи в музей. В таком поведении Назаренко и Семина чувствуется не только негативное отношение к Есипову, но и уверенность их в бесконтрольности своих действий.

В сформировавшейся таким образом обстановке можно предположить, что Семин и Назаренко самостоятельно, т. е. столь же бесконтрольно, принимали решение что и в каком количестве сдать в музей. Этот вопрос решали только они. Сложившаяся обстановка содействовала возможности не сдавать в музей все найденные вещи.

Достаточно быстро, со слов Н.С. Есипова, Семин уехал в Москву, a с А.В. Назаренко они больше не общались. Неизвестно, как А.В. Назаренко и Семин поделили между собой полученные деньги. Со слов сестер Назаренко, Аркадий за сданное золото получил 500 рублей: «Брат получил за находку вознаграждение в размере 500 рублей». В 1939 г. сумма в 500 рублей немного больше месячной зарплаты работника среднего уровня, 400 рублей в месяц получал товаровед отдела снабжения на том же суконном комбинате. 
Cараев В.B. Каргалинская диадема под флером Юрия Домбровского

Далее, по логике действий, события должны были разворачиваться в определенном порядке. Найденное золото официально сдано государству, на место находки направляется археолог для обследования и далее издается статья, описывающая неординарную находку. События с нахождением клада происходили осенью 1939 г., 17 декабря этого же года вышла статья А.Н. Бернштама «Золотая диадема из шаманского погребения на р. Карагалинке» [Бернштам, 1940].

Тем не менее, многое, в действительности, совершалось не так как представляется логикой происхождения событий. Предметное рассмотрение некоторых деталей дает возможность отдельные моменты увидеть под другим углом зрения, более близким к реальности.

Например, в названии статьи «Золотая диадема из шаманского погребения на р. Карагалинке» А.Н. Бернштам употребил неверное название реки. Речь идет о Каргалинской диадеме, селе Каргалы, Каргалинском ущелье, но ученый пишет о погребении на «р. Карагалинке» (выделено авт.).

Любопытно обратиться к сноскам в рассматриваемом тексте. Сноска № 1: «см. газ. "Казахстанская правда" от 27.XI.1939. Находка датировалась IV-VI вв. н.э. Вещи находятся в Центральном музее Казахстана (Алма-Ата)». Эта сноска свидетельствует о том, что якобы в газете вещи датированы IV-VI вв. н.э. на эту мысль, наталкивает слово из сноски: «датировалась» т.е. речь идет как бы об уже свершенном факте. Надо полагать, что А.Н. Бернштаму эта сноска понадобилась затем, чтобы он в своей статье дал другую датировку. Действительно, в указанном издании на c. 31 написано: «Все эти явления дают нам основание сузить возможную датировку (І в. до н.э. - II в. н.э.) и считать I в., может быть II в. наиболее вероятной датой». Таким образом, ученый вносит изменение датировки вещей относительно даты, указанной в статье газеты. Но дело интересно тем, что в газете «Казахстанская правда» от 27.XI.1939 г., на которую указывает А.Н. Бернштам в своей сноске, статьи о Каргалинской находке нет! Вся газета с указанными выходными данными посвящена текущим вопросам своего времени и возможной войне с Германией. Нет ни строчки о находке золотых вещей. Нет подобных статей ни в одном номере газет за октябрь, ноябрь и декабрь 1939 г. Работу по поиску этой статьи проделали в разное время и независимо друг от друга три исследователя, результат один - статьи нет.

Некоторые источники сообщают, что А.Н. Бернштам был первым археологом, раскопавшим Каргалинское захоронение шаманки. Так, в фильме «Каргалинская диадема» (KAZAKHTV Reflections on History) сообщают, что «это была очень тяжелая парадная одежда, не для прогулок» (это о 250 г украшений!?). И утверждают, что первым исследователем «клада» был археолог Бернштам. Эта информация не соответствует действительности. А.Н. Бернштам в статье о Каргалинской находке в сноске № 2 пишет: «Фотографии вещей и материалы обследования присланы В.Ф. Шахматовым», в самом тексте статьи встречается фраза: «Судя по письмам, полученным из АлмаАта...» [Бернштам, 1940, с. 23].

Из чего следует, что статья написана ученым без его личного обследо- 
вания места находки и фактического ознакомления с вещами. Материалы обследования с места находки клада и фотографии его вещей были присланы А.Н. Бернштаму В.Ф. Шахматовым. Виктор Федорович Шахматов в то время занимал должность заведующего историческим сектором в Казахстанском филиале АН СССР (КФАН). В целом руководство работой филиала осуществлялось из центра.

А.Н. Бернштам в 1939 г. проживал в Ленинграде, В.Ф. Шахматов - в Алма-Ате. Первая партия золотых вещей поступила от А.В. Назаренко и, вероятно, Семина. В указанном фильме Назаренко фигурирует как электрик, но Назаренко был токарем, а Семин специалистом по электрооборудованию. На основании этого можно предполагать, что при сдаче вещей в Центральный музей Казахстана всетаки присутствовал Семин. Документ с датой сдачи предметов в настоящее время нам не доступен. Попав в поле зрения исторического сектора КФАН, а, следовательно, и В.Ф. Шахматова, вся работа с этим материалом была под его руководством. Естественно, что отчет об археологической экспедиции, обследовавшей место обнаружения вещей, подписан на имя Шахматова.

По данным из архива Института археологии им. А.Х. Маргулана [Дублицкий, 1939, л. 24-25], документ написан от руки чернильным пером: «КФАН. При этом представляю краткий отчет археологической разведки в окрестностях г. Алма-Аты по заданию Центрального Музея Казахстана, а также ведомости о расходе денег на нее». Документ подписан 16 октября 1939 г. археологом КФАН Дублицким (см. о Б.Н. Дублицком: [Бейсенов и др., 2017, с. 16-17]).
Далее представлено заключение: «КФАН. Представляю заключение по осмотру места залегания костяка человека с золотым инвентарем в долине р. Карагалинка». Документ также подписан археологом КФАН Дублицким, но уже 23 октября 1939 года.

С левой стороны листа документа карандашом наискосок подписано - «Шахматову».

В тексте отчета записано: «Костяк, по заявлению гр. Назаренко, был сильно разрознен и кости, и золотые вещи были разбросаны по всей площади; судя по расположению черепа, направление костяка было с Ю3 на $\mathrm{CB}$, головою на СВ. По заявлению тов. Назаренко, кусок черепа лежал совершенно на поверхности, что и натолкнуло его на раскопку.

Во время проверки выбросов земли, найдено 9 золотых пуговиц и пластинка, тождественная сданным в Республиканский музей».

Далее на обороте: «...Во время осмотра присутствовал директор Республиканского музея т. Пронин и сдатчик золотых вещей... (работник, сотрудник) Алматинской суконной фабрики т. Назаренко. О происхождении находки, сдачи ее т. Назаренко в Республиканский музей, необходимости отыскания у других служащих Алматинской суконной фабрики отдельных золотых вещей из этого за... (хоронения (?)) поставлен в известность директор фабрики; желательно весной 1940 г. углубить на 0,30-0,50 дно». Документ подписан археологом КФАН Дублицким, 23 октября 1939 г.

Акт о сдаче золотых вещей, найденных в результате официально проведенного обследования места находки клада охотниками, подписан 21 октября 1939 г. 
Cараев В.B. Каргалинская диадема под флером Юрия Домбровского

На основании фактов рассмотренных фрагментов документов можно сделать ряд определенных выводов. Неверное, название реки Каргалинка в названии статьи А.Н. Бернштама написано с подачи археолога Б.Н. Дублицкого. Осмотр места проводился в присутствии А.В. Назаренко. Семин отсутствует, так как он уже уехал.

Существует два акта о сдаче золотых вещей из Каргалинского клада. Первый - акт о приеме золотых вещей, найденных охотниками. Второй - акт о сдаче золотых изделий, найденных в результате работы группы специалистов по истории и археологии. Наличие второго акта сдачи вещей в результате работы археологов и могло послужить причиной вывода, что Каргалинский клад найден в результате археологических раскопок. Как об этом написано в тексте энциклопедии «Алма-Ата»: «Каргалинская диадема, <..> найдена в 1939 году во время археологических раскопок в ур. Мыношакты (Каргалинское ущ.) близ Алма-Аты» [Алма-Ата, 1983, с. 293].

Непонятно, когда и по какой причине возникла мысль, что вещи клада охотниками были сданы не полностью. Но Б.Н. Дублицкий счел необходимым в отчете по осмотру местности записать, что директор фабрики поставлен в известность о «необходимости отыскания у других служащих Алматинской суконной фабрики отдельных золотых вещей» [Дублицкий, 1939, л. 24-25]. Так же в рассматриваемом отчете Дублицкого примечательна запись о том, что «желательно весной 1940 г. углубить на 0,30-0,50 дно» [Дублицкий, 1939, л. 24-25], которая свидетельствует о понимании археолога о недостаточности проведенного обследования места и планах на будущий год. Осень 1939 г. была дождливой и холодной.

Остается открытым вопрос относительно статьи в газете «Казахстанская правда» от 27.XI.1939 г. А.Н. Бернштам в разных фрагментах своей статьи пишет, что, судя по письмам, полученным из г. Алма-Ата, фотографии вещей и материалы обследования присланы В.Ф. Шахматовым. Кроме того, он полемизирует с автором статьи в газете по вопросу датировки и это позволяет предположить, что он имел перед собой и газету. Как такое возможно? Каким образом В.Ф. Шахматов мог отослать А.Н. Бернштаму фотографии и материалы обследования места находки вещей вместе с газетой, которой не было?

Осмыслению этого, казалось бы, нелепого обстоятельства, может помочь обращение к условиям того времени. В отчете обследования места Б.Н. Дублицкий указал, что во время осмотра присутствовал директор Республиканского музея т. Пронин и сдатчик золотых вещей т. Назаренко. Таким образом, в экспедиции, о которой сестры Назаренко помнят, что «приехали рано утром археологи на лошадях и попросили Аркадия показать место, где все это было найдено, ему тоже дали лошадь, и он уехал вместе с ними», мог оказаться человек, имеющий связь с газетой «Казахстанская правда». Это, весьма вероятно, был С.М. Пронин.

Степан Митрофанович Пронин, в 1939 г. директор Республиканского музея, рожден в августе 1897 г., в деревне Тульской губернии. Рабочий, плотник, служба в армии с 1916 по 1920 гг. Принят в партию ВКПБ в 1919 г. Все дальнейшие продвижения по социальным позициям происходи- 
ли на поприще агитации и пропаганды. В 1932 г. отмечен как литературный сотрудник газеты «Казахстанская правда». В июне 1938 г. снят с должности комиссара отдела боевой подготовки ЦС ОСОАВИАХИМа КССР (Центрального совета Общества содействия обороне, авиационному и химическому строительству КазССР - прим. авт.) решением бюро ЦК КПК (Центрального комитета коммунистической партии Казахстана - прим. авт.) «как не справившийся с работой» и в июле этого же года назначен директором Центрального исторического краеведческого музея.

Как бывший литсотрудник «Казахстанской правды», С.М. Пронин, будучи директором музея, куда сдали Каргалинский клад, вполне мог написать статью в эту газету. В процессе печатания газет, до выхода их в производство, в типографии набирают так называемый «сигнальный экземпляр». Газеты «сигнального экземпляра» используют для предъявления редакторам с целью устранения ошибок, внесения возможных изменений и т.п. Сверстанный сигнальный экземпляр так же представляли для прочтения в соответствующие госорганы, занимающиеся вопросами цензуры издаваемых материалов. Вероятно, что после прочтения сигнального номера - статья о Каргалинском кладе не получила «добро» на выход в массовый тираж.

Не исключено, что в соавторстве был и Б.Н. Дублицкий, поскольку в статье затрагиваются вопросы датировки древних вещей, с которыми полемизирует А.Н. Бернштам. При сборе посылки для отправки Бернштаму, вместе с фотографиями вещей, отчета осмотра места мог быть вложен и сигнальный экземпляр газеты. Так, газета (сигнальный экземпляр) со статьей о Каргалинской диадеме могла попасть Бернштаму, но не массовому читателю.

После диадемы. Люди. Судьбьл. Любопытно отметить, что все сюжеты произведений, написанные Ю.О. Домбровским о Каргалинском кладе, имеют персонажи расхитителей археологических находок. И в фильме «Шествие золотых зверей», который выпущен в 1978 г. на киностудии «Мосфильм», сценарий к которому Домбровский написал в соавторстве с Т. Вульфович, они присутствуют. Авторы фильма «Каргалинская диадема» (KAZAKHTV Reflections on History) сообщают зрителю, что Домбровский (по свидетельству современников) был арестован и провел несколько месяцев в следственном изоляторе из-за этой диадемы.

Действительно в 1939 г. Ю.О. Домбровский был арестован и отправлен в лагерь на Колыму, где находился до 1943 г. В 1949 г. попал в Тайшетский озерлаг (Иркутская область), где пробыл до 1955 г. Однако есть документ (рис. 6), согласно которому Ю.О. Домбровский 31 марта 1940 г. был осужден сроком «на 8 лет считая срок с 26 августа 1939 года» [Дуардович, 2020]. Из чего следует, что Ю.О. Домбровский не мог провести «несколько месяцев в следственном изоляторе из-за этой диадемы», поскольку он там находился еще до огласки этой истории. Соответственно и на момент появления предметов Каргалинского клада в Центральном историческом краеведческом музее он уже не мог работать «хранителем древностей». Поэтому излагать историю этой находки на свидетельствах произведений Юрия Домбровского 
Cараев B.B. Каргалинская диадема под флером Юрия Домбровского

будет не очень убедительно. Поскольку в их основе творческая фантазия автора. Есть предположение, что Юрий Домбровский «очно» не знаком с находками. Однако в конструкции его произведений использованы факты, перекликающиеся с реальными событиями о каргалинской находке. Юрий Осипович мог их узнать от самого Бориса Николаевича Дублицкого. Постановление на арест Ю.О. Домбровского подписано 31 марта 1940 г., а постановление на арест Б.Н. Дублицкого 27 марта 1940 г., что позволяет предполагать возможность их общения во время предварительного заключения в процессе следствия.
Б.Н. Дублицкий арестован 27.03.1940 г. по статье 58-1а УК РСФСР [Жертвы политического террора. Интернет-ресурс]. Осужден к лишению свободы в исправительнотрудовом лагере сроком на 8 лет. Статья, по которой был осужден археолог, предполагает до 10 лет лишения свободы или даже расстрел. Поэтому план, который наметил Борис Николаевич Дублицкий при осмотре места находки клада, на будущий год: «желательно весной 1940 г. углубить на 0,30-0,50 дно», осуществить не смог.

Что касается жизни А.В. Назаренко после находки клада, то старожилы поселка (Т.Л. Ленский, Мель-

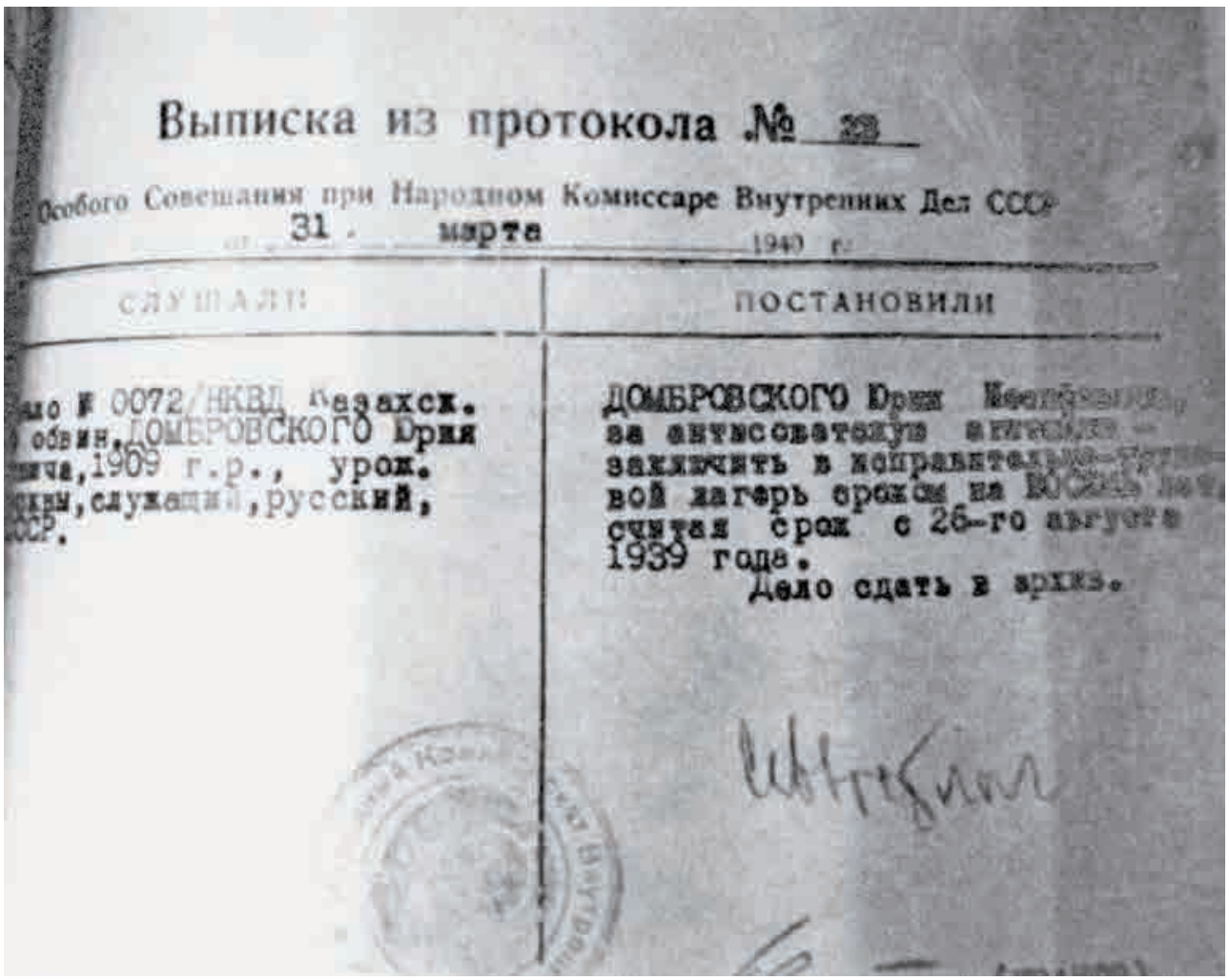

Рис. 6. Выписка из протокола о заключении Ю.О. Домбровского в исправительнотрудовой лагерь от 31 марта 1940 г. (no: [URL: http://lists.memo.ru/d11/f367.htm])

Fig. 6. Extract from the protocol on the imprisonment of Yu. Dombrovskiy in a forced labor camp of March 31, 1940 (by: [URL: http://lists.memo.ru/d11/f367.htm]) 
ников и др.), помнящие события, связанные с этой находкой, не объясняя деталей, все говорили одно: «Лучше бы Аркадий не находил этого золота». Аркадий Васильевич Назаренко, 1913 г.р., был призван на службу в ряды Советской Армии в 1933 г. Служил в сухопутных войсках. В 1936 г. демобилизовался, устроился на работу, женился. Со слов старшей сестры Зои Васильевны Ключниковой: «Аркадий весной, в марте месяце 1941 г., получил повестку явиться в поссовет, где ему сообщили, что его, как хорошего специалиста, призывают на укрепление государственной границы». Зоя Васильевна также сказала, что в назначенный день в поссовете было накрыто небольшое застолье со спиртным. Там сообщили, что Аркадия, как хорошего токаря, и с ним еще 8 человек из поселка, специалистов других профессий, призывают на укрепление государственной границы. Этот призыв Аркадия в армию был несколько необычным. Получается, что его вторично призвали на службу в армию ещё до нападения фашистской Германии на СССР. Всеобщая мобилизация рабочих суконного комбината на фронт происходила в июле 1941 г.

Со слов сестер Аркадия, их брат погиб в первые дни войны. После окончания войны им не удалось найти даже следов его пребывания в армии. «Мы обращались в архив Советской Армии, не было ничего о нашем брате, даже того, что он был призван в армию», - вспоминает сестра Аркадия - Юлия. И только с помощью «влиятельного знакомого из Москвы» значительно позже удалось выяснить, что А.В. Назаренко служил в частях НКВД (Народный комиссариат внутренних дел) и строил оборонитель- ные сооружения на границе, там погиб, есть место его захоронения, о чем сообщили сестры Аркадия.

В сентябре 2002 г., при неожиданной встрече с дочерью Аркадия Назаренко, Любовь Аркадьевна рассказала со слов ее матери, что «...в марте 1941 г. отца призвали на работу в трудармию. Эшелон охранялся работниками НКВД. Мама ездила туда к нему (как я понял, жена Аркадия ездила на железнодорожную станцию, где формировался эшелон - прим. авт.). В поселке проводили на эти работы многих людей. Формирование этой группы велось секретно, под видом формирования части из лучших специалистов различного профиля. Из писем, которые присылал отец, было ясно, что на месте их держали в очень плохих условиях и плохо кормили. В письме он просил прислать сухарей и что-нибудь теплое. Жили в каких-то бараках под охраной. Bce письма и фотографии Аркадия уничтожил позднее ее отчим». Так сложились судьбы людей, столкнувшихся с Каргалинским кладом.

«Тайное» место. Поиски, ошибки и находки

Одним из важнейших вопросов, связанных с Каргалинской находкой, был вопрос о месте нахождения этих вещей. А.Н. Бернштам в своей статье «Золотая диадема из шаманского погребения на р. Карагалинке» сообщает, где были найдены вещи: «В 1939 г. в правом ответвлении Карагалинского ущелья (Алма-Атинская обл.), близ урочища Мынг Ошакты на высоте 2300 м над ур.м., ... были найдены кости человека с набором золотых предметов... Скелет был найден в расщелине скалы...» [Бернштам, 1940, с. 23]. Но воспользоваться этими све- 
Cараев B.B. Каргалинская диадема под флером Юрия Домбровского

дениями для нахождения места находки невозможно. О левом ответвлении Каргалинского ущелья он говорит, как о «правом ответвлении Карагалинского ущелья». Сведение о том, что место находится «...близ урочища Мынг Ошакты» не помогают решению вопроса, поскольку на всех доступных картах региона п. Фабричный нет урочища с таким названием. Были просмотрены не только туристические, геологические, административные, но и карты специального назначения: военные, «полетные», землепользования хозяйств Жамбылского района. Ни на одной из них не присутствует топоним «Мынг Ошакты» (в переводе с каз.яз. «Тысяча огней» или «Тысяча очагов» - прим. авт.). Однако сведения о месте находки вещей из указанной статьи используют в таком виде десятки лет.

Решению вопроса не способствовал опрос местных чабанов и старых жителей поселка. Жители поселка Фабричный, которые хоть както помнили о находке золота в 1939 г., говорили: «...где-то в горах, в пещере». Поэтому параллельно сбору различных сведений у местных жителей и особенно охотников приходилось выяснять, где есть пещеры. Согласно устному сообщению кандидата геологических наук Г.Б. Паршина, геоморфология гор у поселка не предполагает образования пещер. Сведений о местах, которые условно можно назвать пещерой набралось пять. Три грота находящиеся выше района, на сленге местных жителей «развилок» (название топографической привязки у местных жителей - прим. авт.), можно было исключить, поскольку Н.С. Есипов говорил, что «место находится к поселку ближе развилок». Четвертое место в «правой щели» тоже не подходящее - оно находится рядом с поселком (2 км) и останавливаться в ней на ночлег, возвращаясь с охоты, не было смысла.

Оставалась только одна из известных «пещер», которая находилась в ущелье Ерменсай. О ней мне рассказал мой друг Александр Михайлович Нечухранный (рис. 7). Он ее обнаружил в 1977 г. В этой пещерке сидело несколько молодых людей у костра. Но она расположена далековато от дороги с гор в поселок. Вместе с тем, мало ли куда могло занести охотников.

Однажды мне довелось присесть на уличную скамью на улице поселка. На ней сидел пожилой мужчина. Разговорились. Он сказал, что родился в этом поселке, и вся его жизнь прошла здесь. Естественно,

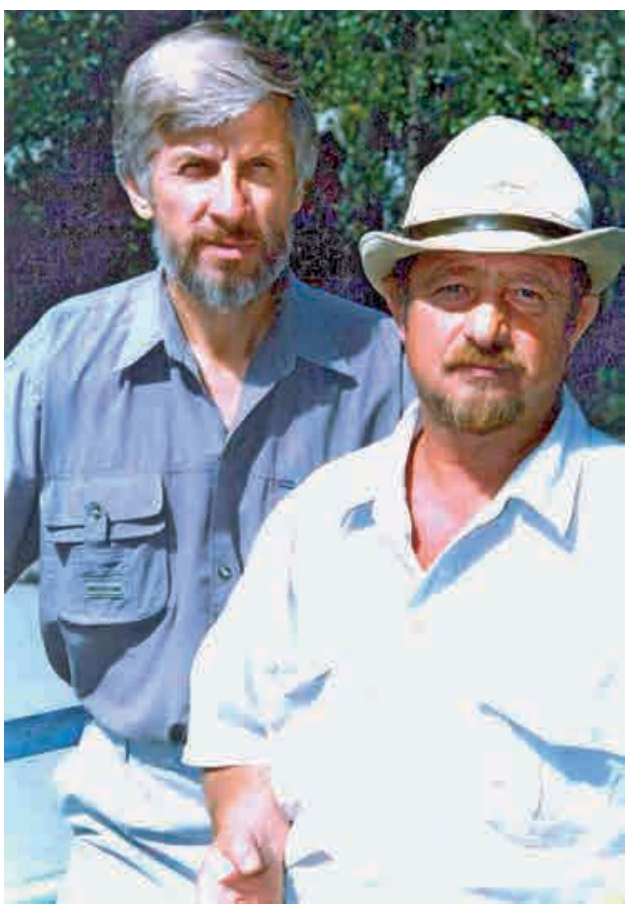

Рис. 7. В.В. Сараев с А.М. Нечухранным. Фото из семейного архива В.В. Сараева

Fig. 7. V. Saraev with A. Nechukhrannyi. Photo from the family archive of $V$. Saraev 
что спросил его о находке золота в горах. Он ответил, что сам лично он об этом ничего не знает, поскольку был маленьким, но помнит, что взрослые рассказывали, как в горах под какимто камнем охотники нашли много золота в ущелье Ерменсай. Пришлось ему сказать, что в документах говорится об урочище «Мынг Ошакты». И этот человек (сожалею, что не записал его фамилии) сказал, что Ерменсай это и есть Мынг Ошакты. После войны, говорил он, здесь было много разных людей с приборами, и они все измеряли и переименовывали. Делали новые карты. После них Мынг Ошакты стали называть Ерменсай. Потому что это ущелье все заросшее всяким кустарником и травой, так что по нему пройти невозможно. Чабаны так и называли это ущелье между собой, а потом так стало на картах. Таким образом, собранные сведения как бы сошлись в одну точку. Тут и пещера, в которой несколько человек разводят костерок, и место, которое ранее называли «Мынг Ошакты», и достаточно дикая природа, что немаловажно для охоты.

Поэтому летом 2000 г. мы с А.M. Нечухранным пошли к этой пещере (рис. 8). Поход проходил сложно. Часто начинался дождь. Самым трудным для прохождения оказался участок непосредственно по ущелью Ерменсай. Никаких троп, даже оставленных животными, уже не было. Приходилось пробираться сквозь бесконечный кустарник, еще и под дождем. К пещере подошли, когда уже село солнце. Пришлось здесь остаться на ночь. В такой пещерке могли разместиться 3-4 человека и при наличии сухих дров можно было развести костер. По дороге к пещере и обратно (в 1992 г. уже был мой поход в этот район Каргалинского ущелья - прим. авт.) мы увидели большое количество различных исторических объектов: развалившиеся каменные постройки, курганы, наскальные рисунки и т. п.

Однако ночь, проведенная в этой пещере, поставила и некоторые вопросы, на которые нет ответа. Например, было непонятно, как Б.Н. Дублицкий мог планировать на будущий год углубить раскоп близ захоронения, если пещера, в которой довелось ночевать, была сплошь каменная? Этот и другие вопросы не состыковывались с тем, что доводилось слышать от людей и что удалось увидеть. Однако это была единственная пещера ущелья Ерменсай.

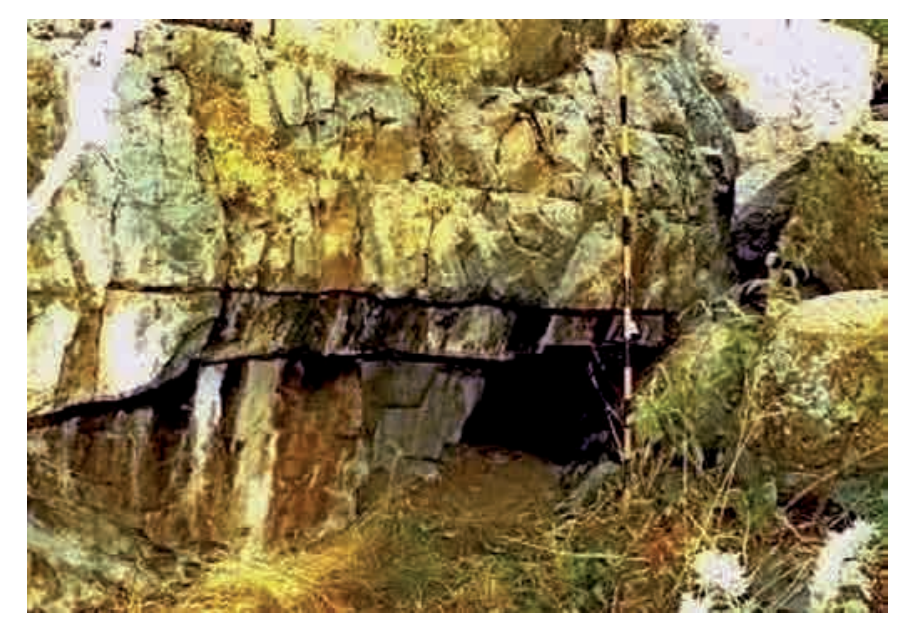

Рис. 8. Ущелье Ерменсай. «Пещера Нечухранного А.М.». Фото В.В. Сараева

Fig. 8. Ermensai Gorge. "Cave of Nechukhrannyi A.M." Photo by V. Saraev 
Cараев B.B. Каргалинская диадема под флером Юрия Домбровского

Письменно изложив свои соображения и наблюдения, приложив фотографии, я обратился в Институт археологии им. А.Х. Маргулана с предложением провести детальное обследование этого места. Так моя фотография этой пещеры оказалась в известной книге «Древности Алматы» (рис. 8) [Самашев и др., 2005, с. 113]. Возврат в настоящее время к этому факту обусловлен желанием посильно уменьшить распространение недостоверной информации о месте находки Каргалинского клада. Это не та пещера. Это было моей ошибкой. Долгое время пещеру на фото я считал тем местом, где была найдена диадема.

Bce изменилось после моего знакомства с Ермеком Менянбаевым. Будучи корреспондентом газеты «Я покупатель, я собственник», он со своей семьей переехал жить в поселок из Алматы. Этот любознательный человек интересовался краеведением и неоднократно осматривал окрест- ности поселка. В 2019 г. он обратился ко мне с просьбой показать на карте место, где была найдена диадема. Понимая всю сложность объяснения, где находится эта пещера, я указал место, где ущелье Ерменсай выходит к основному ущелью Каргалы. Через несколько дней Ермек сообщает мне, что он нашел эту пещеру. Мое сильное удивление Ермек дополнил тем, что как профессиональный корреспондент он все отснял фотоаппаратом. На его фото я увидел те подробности и отдельные детали, которых не было в пещере, которую мы нашли с А.М. Нечухранным.

Я сказал Ермеку, что он нашел место, где действительно была найдена диадема. На что он ответил: «Ведь вы сами указали мне это место». По стечению обстоятельств я «ткнул пальцем» (явно сработал «Господин Случай») туда, где располагался огромный камень. На фотографиях Ермека Менянбаева было видно, что

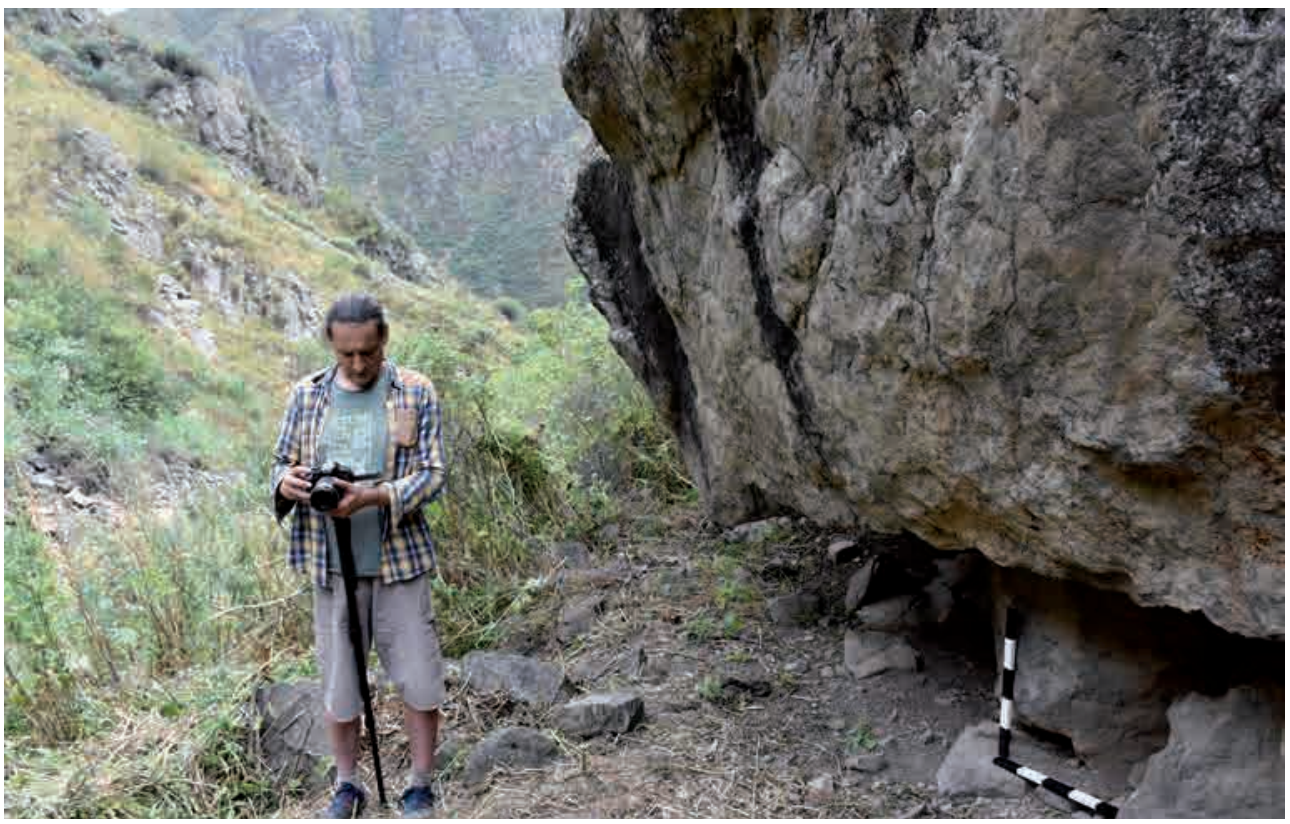

Рис. 9. Ермек Менянбаев у Каргалинского камня. Фото Т.А. Егоровой

Fig. 9. Ermek Menyanbaev at the Kargaly stone. Photo by T. Yegorova 


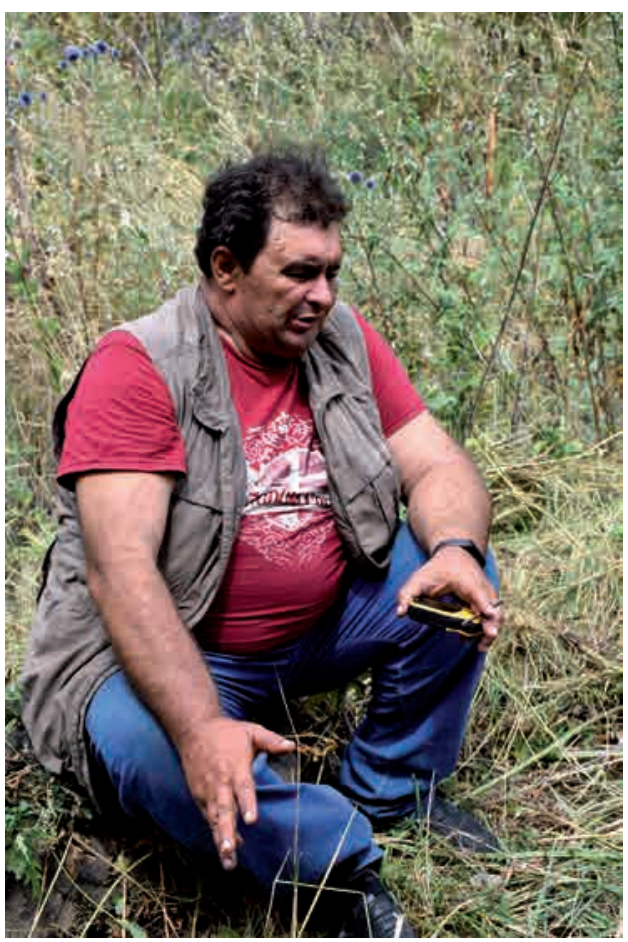

Рис. 10. Археолог А.А. Горячев. Фото Т.А. Егоровой

Fig. 10. Archaeologist A. Goryachev. Photo by T. Yegorova

в нише под камнем могли расположиться несколько человек, пол ниши был земляным и его действительно можно углубить, как это планировал когда-то Б.Н. Дублицкий. Свод ниши имел налет копоти, на полу валялись сухие палки, деревяшки, было много сухой травы. Более того, под камнем, внутри ниши, просматривались сложенные когда-то стенки из мелких камней и промазанные глиной, разрушенные в настоящее время, и лежали какие-то косточки.

Человек, чье сознание не было занято поиском каких-то пещер, как об этом свидетельствовали «знающие люди», и не ищущий расщелины в скале, как об этом писал А.Н. Бернштам в своей статье: «...Скелет был найден в расщелине скалы...» [Бернштам, 1939, с.23], Ермек, благодаря своему воображению, влез под приметный камень в месте, которое ему указали на карте. И нашел то, что ждало своего «открытия» (рис. 9). С этой информацией и объяснением обстоятельств дела мы с Е. Менянбаевым обратились к директору Института археологии им. А.Х. Маргулана Б.А. Байтанаеву. В результате чего на место был направлен небольшой археологический отряд под руководством А.А. Горячева* (рис. 10), который в июле-августе 2020 г. в сопровождении Ермека Менянбаева и группы поддержки неравнодушных к родной истории ребят произвел там первые полноценные рекогносцировочные исследования, получив материалы, доказывающие идентичность исследованного объекта с местом находки Каргалинского клада. Предваряя научные публикации по результатам работ, могу отметить, что это уникальный случай в погребальной практике племен раннего железного века, как по структуре организации комплекса, так и по особенностям обряда захоронения.

\section{Заключение}

В заключение этой непростой истории уместно сказать, что археологом из Ленинграда, которого Н.С. Есипов сопровождал к месту находки, был, вероятно, А.Н. Бернштам. В сво-

*A.А. Горячев - старший научный сотрудник Института археологии им. А.Х. Маргулана. На протяжении ряда лет консультирует В.В. Сараева - автора и соавтора ряда работ по археологии Жетысу (см. напр. [Сараев, Кожегулова, 2019; Горячев и др., 2021]). (Прим. ред.).) 
Cараев B.B. Каргалинская диадема под флером Юрия Домбровского

их воспоминаниях Н.С. Есипов отмечает, что «...через некоторое время к нам приехал из Ленинграда археолог, фамилию его я не помню, не знаю, помню, что это был человек лет под пятьдесят, прихрамывал. Я сопровождал его к месту находки. Ехать на лошади он отказался и просил не показывать места находки». Так описан «археолог из Ленинграда» в редакции П.А. Яковенко, но на словах Есипов высказал предположение, что у него был, возможно, деревянный протез (нога не сгибалась), и ходил он с палочкой. Много позже удалось выяснить, что у Александра Натановича Бернштама был анкилоз колена - оно не гнулось, ходил ученый с палкой и выглядел значительно старше своих лет.

Поднимались они в горы, вероятно, в начале лета 1941 г. (до начала Великой Отечественной войны). Поскольку со слов дочери Аркадия Назаренко: «...В марте 1941 г. отца призвали на работу в трудармию». А.В. Назаренко не было, Б.Н. Дублицкий был осужден, С.М. Пронин - снят с должности директора музея. Таким образом, А.Н. Бернштама на место находки вещей мог сопроводить только Н.С. Есипов. Эта информация дополнительно подтверждает, что А.Н. Бернштам не мог быть первым исследователем «захоронения жрицы» и посетил он место находки Кар- галинского клада значительно позже написания своей статьи об этом захоронении.

На встрече с дочерью А.В. Назаренко в 2002 г. Любовь Аркадьевна (1938 г.р.) рассказала, что золото из этого клада (в том числе большая квадратная бляшка с изображениями козликов внутри) хранилось у них в семье в тряпочном мешочке. Основное количество использовали на свои нужды (продали) ее отчим и брат по матери. Оставшиеся несколько пластинок Любовь Аркадьевна хранила у себя. В 1996 г. она отдала их своему сыну, который после службы в армии решил жениться и использовал их для изготовления обручальных колец (в память о дедушке - А.В. Назаренко). Золото (4,5 г) ювелиры обменяли на простые обручальные кольца. Эти сведения Любови Аркадьевны дают основание полагать, что в 1939 г., как и предполагалось, А.В. Назаренко и Семин действительно не все найденные вещи сдали в музей и часть их, возможно, хранится в семье Семина в Москве.

Благодарности. Особую благодарность за сбор информации хочется выразить Юрию Аркадьевичу Мотову, Жаннетте Петровне Ананьевой, Александру Михайловичу Нечухранному и Лидии Федоровне Митах.

\section{ЛИТЕРАТУРА}

1. Бейсенов А.З., Джумабекова Г.С., Базарбаева Г.А. Путь к изучению древностей центра страны: история создания первой археологической экспедиции Казахской Академии наук // Археологическое наследие Центрального Казахстана: изучение и сохранение: сб. научн. ст., посвящ. 70-летию организации ЦКАЭ Академии наук Казахстана / отв. ред. А.З. Бейсенов, В.Г. Ломан. Алматы: НИЦИА «Бегазы-Тасмола», 2017. T. 1. C. 11-64.

2. Бернштам А.Н. Золотая диадема из шаманского погребения на р. Карагалинке // КСИИМК. 1940. Вып. V. С. 23-31. 
3.Горячев А.А., Сараев В.В., Егорова Т.А., Чернов М.А. Новые материалы древнего археологического комплекса Каргалинского историко-географического микрорайона // Археология Казахстана. 2021. № 2 (12). С. 69-101.

4. Дуардович И. Он Ленина на *** послал. Неизвестное уголовное дело Юрия Домбровского // Дилетант. 24.07.2020. URL: https://diletant.media/articles/45291133/

5. Дублицкий Б.Н. Заключение по осмотру места залегания костяка человека с золотым инвентарем в долине р. Каргалинке близ Алматинской суконной фабрики. 1939 г. В: Хроника археологических разведок и находок на территории Казахской ССР (1928-1938 гг.) // Архив Института археологии им. А.Х. Маргулана, ф. 11, оп. 2, д. 36, л. 24-25. f367.htm

6. Жертвы политического террора в CCCP. URL: http://lists.memo.ru/d11/

7. Нифонтова Л.К. Последние археологические поступления в Центральный государственный музей Казахской ССР // Известия АН КазССР. Сер. археол. 1948. Вып. 1. С. 116-124.

8. Самашев 3., Григорьев Ф., Жумабекова Г. Древности Алматы. Алматы: ТОО «Археология», 2005. 184 с.

9. Сараев В.В., Кожегулова Ф.Т. О способах обогрева древних землянок в предгорной и горной зоне Илейского Алатау // Археология Казахстана. 2019. № 1 (3). C. $28-42$.

10. Энциклопедия «Алма-Ата». Алма-Ата: Гл. ред. казахской советской энциклопедии, 1983. 608 с.

\section{REFERENCES}

1. Beisenov, A. Z., Jumabekova, G. S., Bazarbayeva, G. A. 2017. In: Beisenov, A. Z., Loman, V. G. (eds.). Arheologicheskoe nasledie Centralnogo Kazahstana: izuchenie i sohranenie (Archaeological Heritage of Central Kazakhstan: study and protection), 1, 11-64. Almaty: "Begazy-Tasmola" Publ. (in Russian).

2. Bernshtam, A. N. 1940. In: Kratkie soobshcheniya Instituta istorii materialnoy kultury (Brief reports of the Institute for the History of Material Culture), V, 23-31 (in Russian).

3. Goryachev, A., Saraev, V., Egorova, T., Chernov, M. 2021. In: Kazakhstan Archeology, 2 (12), 69-101 (in Russian).

4. Duardovich, I. 2020. In: Diletant (Diletant) URL: https://diletant.media/ articles/45291133/ (in Russian).

5. Dublitskiy, B. N. 1939. In: Archive of the A.Kh. Margulan Archeology Institute, f. 11, d. 36 (in Russian).

6. In: URL: http://lists.memo.ru/d11/f367.htm (in Russian).

7. Nifontova, L. K. 1948. In: Izvestiya AN KazSSR (Izvestia of the Academy of Sciences of the Kazakh SSR), 1, 116-124 (in Russian).

8. Samashev, Z., Grigoriev, F., Jumabekova, G. 2005. Drevnosti Almaty (Antiquities of Almaty). Almaty: "Arheologiya" (in Russian).

9. Saraev, V. V., Kozhegulova, F. T. 2019. In: Kazakhstan Archeology, 1 (3), 28-42 (in Russian).

10. Enciklopediya «Alma-Ata» (Encyclopedia “Alma-Ata”). Alma-Ata: Glavnaya redakciya kazahskoy sovetskoy enciklopedii, 1983 (in Russian).

\footnotetext{
Мүдделер қақтығысы туралы ақпаратты ашу. Автор мүдделер қақтығысының жоқтығын мәлімдейді.

/ Раскрытие информации о конфликте интересов. Автор заявляет об отсутствии конфликта интересов.

/ Disclosure of conflict of interest information. The author claim no conflict of interest.
}

Мақала туралы ақпарат / Информация о статье / Information about the article.

Редакцияға түсті / Поступила в редакцию / Entered the editorial office: 03.06.2021.

Рецензенттер мақұлдаған / Одобрено рецензентами / Approved by reviewers: 12.06.2021.

Жариялауға қабылданды / Принята к публикации / Accepted for publication: 15.06.2021. 